\title{
Effects of different doses of fertilizers in combination of bio-fertilizers with organic manure on growth parameters yield and yield attributes of French bean
}

Santosh Kumar, Jotish Nongthombam, K.P. Chaudhary, Nitin Kumar Pandey, Om Prakash and Mandhata Singh

Received : 23.08.2018; Revised : 14.11.2018; Accepted : 23.11.2018

$\overline{\text { MEMBERS OF RESEARCH FORUM: }}$

Corresponding author :

Santosh Kumar, Krishi Vigyan

Kendra (C.A.U.), Aizawl

(Mizoram) India

Email: santosh.veg@gmail.com

Co-authors :

Jotish Nongthombam and K.P. Chaudhary, Krishi Vigyan Kendra

(C.A.U.), Aizawl (Mizoram) India

Nitin Kumar Pandey, Krishi Vigyan Kendra (B.U.A.T.), Lalitpur (U.P.) India

Om Prakash, Krishi Vigyan Kendra, Khawzawl (Mizoram) India

Mandhata Singh, Krishi Vigyan Kendra (ICAR-RC), Buxar (Bihar) India

\section{Summary}

Potentiality of three organic manure namely vermicompost, farmyard manure (FYM) and poultry manure (PM) vis-à-vis, 0 per cent to100 per cent recommended dose of fertilizer - NPK in French bean (Variety: Arka Anoop). Field experiment was conducted in cluster form at Sihphir venghlun village, Aizawl district in Mizoram, NEH Region, India during the year 201516. Among the various treatments 75 per cent RDF along with 25 per cent RDF met from vermicompost along with bio-fertilizer $\left(\mathrm{T}_{2}\right)$ application produced better result in terms of germination per cent $(85.34 \%)$, number of pod per plant (20 number), pod yield per plant $(300.05 \mathrm{~g})$ and pod yield (14.00 t/ha). And was found to give more remunerative and advantageous in respect of maximum net return (Rs. 254000.00) and cost: benefit ratio (2.64) when compared to other treatments.

Key words : Arka anoop, Vermicompost, FYM, PM, Bio-fertilizer, Pod yield, RBD

How to cite this article : Kumar, Santosh, Nongthombam, Jotish, Chaudhary, K.P., Pandey, Nitin Kumar, Prakash, Om and Singh, Mandhata (2018). Effects of different doses of fertilizers in combination of bio-fertilizers with organic manure on growth parameters yield and yield attributes of French bean. Asian J. Soil Sci., 13 (2) : 148-152 : DOI : 10.15740/HAS/AJSS/13.2/148-152. 